\title{
CROSS NEUTRALIZING ANTIBODIES IN HAMSTERS VACCINATED WITH LEPTOSPIRAL BACTERINS PRODUCED WITH THREE SEROVARS OF SEROGROUP SEJROE
}

\author{
Rosana Tabata $^{1 *}$; Hugo Scanavini Neto ${ }^{2}$; Marcelo Alexandre Fagnani Zuanaze ${ }^{2}$; Eugenia Márcia de Deus Oliveira ${ }^{1}$; \\ Ricardo Augusto Dias ${ }^{1}$; Zenaide Maria de Morais ${ }^{1}$; Fumio Honma Ito ${ }^{1}$; Silvio Arruda Vasconcellos ${ }^{1}$ \\ ${ }^{1}$ Departamento de Medicina Veterinária Preventiva e Saúde Animal, Faculdade de Medicina Veterinária e Zootecnia, \\ Universidade de São Paulo, São Paulo, SP, Brasil. ${ }^{2}$ Laboratórios Biovet S/A, Vargem Grande Paulista, São Paulo, SP, Brasil
}

Submitted: June 16, 2002; Approved: September 24, 2002

\begin{abstract}
Three leptospiral bacterins, produced with different serovars of Serogroup Sejroe, namely the hardjo (bacterin A), wolffi (bacterin B) and guaricura (bacterin C), were evaluated in male hamsters (Mesocricetus auratus) by comparing the agglutinating and neutralizing antibodies titers using microscopic agglutination (MAT) and in vitro growth inhibition (GIT) tests. The immunization schedule was based on two $1.0 \mathrm{~mL}$ doses of non-diluted formalin-inactivated whole culture bacterin given through subcutaneous route with 10-day interval. The challenge was performed ten days after the second vaccine dose, when the animals were inoculated with 0.2 $\mathrm{mL}$ of non-inactivated cultures of each serovar through intraperitoneal route. On the $21^{\text {st }}$ post-challenge day (PCD), all animals were bled and their sera were joined in pools $(n=8)$ and tested by MAT and GIT. All vaccinated and control animals presented no clinical signs of leptospirosis after the challenge, but the serovar guaricura was isolated from the kidneys of control animals on the $21^{\text {st }} \mathrm{PCD}$. The MAT results showed cross agglutinins between serovars hardjo and wolffi, and between wolffi and guaricura. The GIT results revealed the presence of cross neutralizing antibodies between serovars wolffi or guaricura against hardjo, wolffi and guaricura. It was found that the tested strain of serovar hardjo did not produce detectable levels of neutralizing antibodies, indicating its poor immunogenicity.
\end{abstract}

Key words: Leptospira, bacterins, hamsters, neutralizing antibodies, Serogroup Sejroe

\section{INTRODUCTION}

Bacterins are widely used for preventing clinical leptospirosis $(9,13,14)$, renal colonization by leptospires $(9)$, agalactia (22), abortions and productive losses in animals. The immunizing activity is increased by the addition of proper adjuvants as aluminum hydroxide (13).

In Brazil, serological surveys in cattle and bubaline herds showed that serovars hardjo $(1,8,15,17,21,28)$ and wolffi $(4,8,11,12,15,16,21,23)$, both belonging to Serogroup Sejroe, were the most frequent. However, only serovars hardjo (18) and guaicurus $(24,29,30)$ have been isolated from these animal species and typed, the last one was registered by Tropical Royal Institute of Amsterdam, Netherlands, with the name guaricura.
Leptospiral bacterins must contain the lowest number of serovars as possible, mainly with those isolated in each region (31). In Brazil, the microscopic agglutination test (MAT) results of bovine sera showed cross agglutinating reactions between serovars guaicurus and wolffi (30), and between hardjo and wolffi (8). The evidence of cross-protection against challenge with serovar hardjo in hamsters vaccinated with hardjo or wolffi bacterins were also found (6). These observations emphasize the need of new investigations searching for the presence of cross neutralizing antibodies in animals vaccinated with different serovars of the same serogroup, which was the objective of this research, employing the in vitro growth inhibition test (GIT), as recommended by Tripathy et al. (26).

\footnotetext{
* Corresponding author. Mailing address: Departamento de Medicina Veterinária Preventiva e Saúde Animal - FMVZ - USP. Av. Prof. Dr. Orlando Marques de Paiva, 87, Cidade Universitária, 05508-900, São Paulo, SP, Brasil. Tel.: (+5511) 3091-7653, Fax: (+5511) 3091-7928. E-mail: rtabata@usp.br
} 


\section{MATERIALS AND METHODS}

\section{Bacterins}

Three bacterins with aluminum hydroxide as adjuvant, inactivated by $10 \%$ formaldehyde solution, were produced by Laboratórios Biovet S/A (Vargem Grande Paulista, Brazil), each of them including one serovar of Serogroup Sejroe: Leptospira interrogans serovar hardjo strain Hardjoprajitno (bacterin A), L. interrogans serovar wolffi strain 3705 (bacterin B) and $L$. santarosai serovar guaricura strain M04/98 (bacterin C).

\section{Animals}

Seventy-two young male hamsters (Mesocricetus auratus), weighting 80 to $120 \mathrm{~g}$, clinically healthy, were distributed into three groups with twenty-four individuals and vaccinated with bacterins A, B and C, respectively

Eighteen animals, with the same characteristics as those in groups above, were kept as the negative control group. They received two $1.0 \mathrm{~mL}$ doses of saline solution by subcutaneous route with 10-day interval and ten days after the second dose, they were inoculated with $0.2 \mathrm{~mL}$ of Sorensen phosphate buffer saline. After 21 days, they were bled and sera of each six animals were joined, resulting in three pools, which were respectively tested against serovars hardjo, wolffi and guaricura by MAT and GIT.

Eighteen animals, with the same characteristics as those in groups above, were kept as the non-vaccinated control group, which received two $1.0 \mathrm{~mL}$ doses of saline solution by subcutaneous route with 10-day interval. After ten days, the animals were distributed into three groups with six individuals, which were respectively challenged by intraperitoneal route with $0.2 \mathrm{~mL}$ of live cultures of leptospires included in the bacterins diluted in Sorensen phosphate buffer saline presenting 20 to 30 bacteria per microscopic field $(200 \mathrm{x})$. On the $21^{\text {st }}$ post-challenge day (PCD), they were necropsied and their kidneys were aseptically collected for detection of kidney carriers of leptospires.

\section{Immunization Schedule (27)}

The immunization schedule was two $1.0 \mathrm{~mL}$ doses of nondiluted vaccines given through subcutaneous route with 10day interval. After ten days from the second vaccine dose, the animals were challenged by intraperitoneal route with live cultures of leptospires included in the bacterins diluted in Sorensen phosphate buffer saline and presenting 20 to 30 bacteria per microscopic field ( $200 \mathrm{x})$. On the $21^{\text {st }} \mathrm{PCD}$, all animals were bled, and the sera of each eight animals were joined, resulting in three pools, which were respectively tested against serovars hardjo, wolffi and guaricura by MAT and GIT.

\section{Microscopic Agglutination Test (MAT) - Galton et al. (10)}

MAT was carried out with live cultures of serovars hardjo, wolffi and guaricura, grown in modified EMJH (Difco
Laboratories - USA) (2), and incubated at $28^{\circ} \mathrm{C}$ for 14 days. Serological reactions at 1:100 dilution or higher were considered as positive when $50 \%$ of the leptospires were agglutinated. The titer was given as reciprocal of the highest dilution where 50\% of leptospires still agglutinated $(5,19)$.

\section{In vitro Growth Inhibition Test (GIT) - Tripathy et al. (26)}

The serum pools were tested in double dilutions (1:1 to 1:16) prepared in Sorensen phosphate buffer saline. For each serum dilution, an amount of $0.2 \mathrm{~mL}$ was distributed in each of five tubes containing $2.5 \mathrm{~mL}$ of modified EMJH and $0.1 \mathrm{~mL}$ of a live culture of one serovar of leptospires with 14 days of growth in modified EMJH. The tubes were incubated at $28^{\circ} \mathrm{C}$ for ten days. The presence of ringer growth was considered as positive growth, but the presence of leptospires was also confirmed by microscopic dark field examination. Absence of growth and presence of few leptospires were considered as growth inhibition, promoted by neutralizing antibodies (26). The serum dilution that could inhibit the leptospires growth in $50 \%$ of tubes was calculated by Reed \& Müench method (16), and the confidence intervals were calculated as described by Pizzi (20).

\section{Kidney carrier state}

The kidneys aseptically collected were individually triturated and suspended in Sorensen phosphate buffer saline, resulting in three 10 -fold dilutions $\left(10^{-1}\right.$ to $\left.10^{-3}\right)$. For each dilution, an amount of $0.1 \mathrm{~mL}$ was distributed in each of two tubes containing $5.0 \mathrm{~mL}$ of Fletcher medium (19), which were incubated at $28^{\circ} \mathrm{C}$ for 42 days, with weekly observations (7) destined to verify the Dinger zone (19), and the presence of leptospires was also confirmed by microscopic dark field examination.

\section{RESULTS AND DISCUSSION}

In negative control group, all sera were negative in MAT, and there was no growth inhibition of leptospires in any serum dilution.

In non-vaccinated control groups, there were no deaths due to the challenge, and the animals did not present kidney infection by serovars hardjo and wolffi, probably because of the loss of pathogenicity of these strains, which have been maintained in vitro conditions for a long time, but there were six kidney carriers for serovar guaricura, isolated from a buffalo recently (29), which maintain the characteristic capacity of kidney infection.

The MAT results (Table 1) were analyzed by the software SPSS 10.07 for Windows. There was not significant statistical difference between the agglutinating antibodies titers induced by bacterin A (serovar hardjo) and B (serovar wolffi) against serovar hardjo $(p=0.435)$ and against wolffi $(p=0.064)$; the agglutinating antibodies titers induced by bacterin $\mathrm{B}$ (serovar 
wolffi) and C (serovar guaricura) were not statistically different against serovar guaricura $(\mathrm{p}=0.222)$.

The agglutinating antibodies response induced by bacterin A (serovar hardjo) against serovars hardjo and wolffi was lower than that induced by bacterin B (serovar wolffi), which induced lower agglutinins response against serovar guaricura than bacterin $\mathrm{C}$ (serovar guaricura). Although not statistically significant, these results revealed cross-reactions of agglutinins between serovars hardjo and wolffi, and between wolffi and guaricura.

The GIT neutralizing antibodies titers were analyzed as Pizzi (20). The results showed that bacterin A (serovar hardjo) induced no neutralizing antibodies response against serovars hardjo and guaricura, but only against serovar wolffi; and bacterins B (serovar wolffi) and C (serovar guaricura) induced neutralizing antibodies against serovars hardjo, wolffi and guaricura. The $95 \%$ confidence intervals of neutralizing antibodies induced by bacterins B (serovar wolffi) and C (serovar guaricura) indicated the presence of cross neutralizing activity of serovar included in the vaccine against the other three serovars employed as antigens (Figure 1).

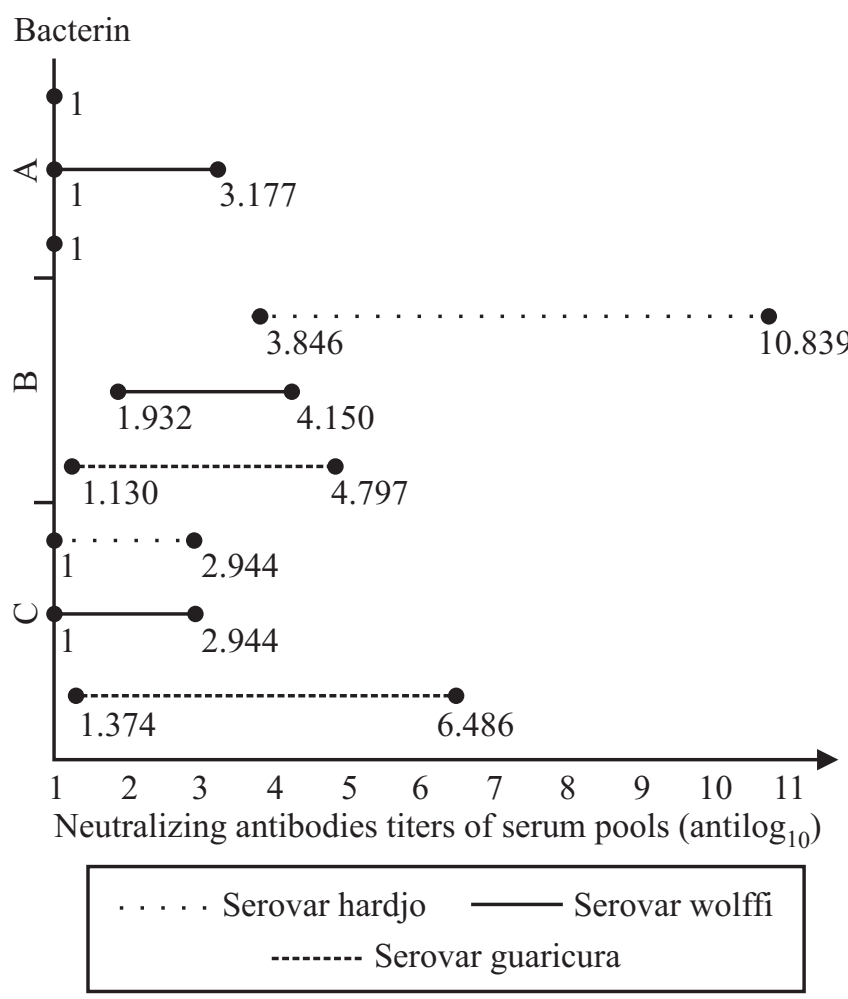

Figure 1. Geometric mean and $95 \%$ confidence intervals of neutralizing antibodies titers, expressed in antilog ${ }_{10}$, of serum pools from vaccinated hamsters, according to the bacterin and the serovar of Serogroup Sejroe employed as antigen in the growth inhibition test. São Paulo, 2001.
Table 1. Agglutinating antibodies titers against leptospires of serum pools from vaccinated hamsters, expressed in arithmetic mean and $95 \%$ confidence intervals, values in $\log _{10}$, according to the bacterin and the serovar of Serogroup Sejroe employed as antigen in the microscopic agglutination test (MAT). São Paulo, 2001.

\begin{tabular}{cccc}
\hline \multirow{2}{*}{ Bacterins } & \multicolumn{3}{c}{ Serovar employed as antigen in the MAT } \\
\cline { 2 - 4 } & hardjo & wolffi & guaricura \\
\hline A & $1.636 \pm 1.486$ & $0.668 \pm 1.157$ & 0 \\
B & $2.603 \pm 0$ & $2.229 \pm 0.287$ & $1.077 \pm 1.249$ \\
C & 0 & 0 & $2.154 \pm 0.173$ \\
\hline
\end{tabular}

Bacterin A: serovar hardjo; Bacterin B: serovar wolffi; Bacterin C: serovar guaricura.

The worst performance of bacterin A (serovar hardjo) against serovar hardjo could be explained by the poor immunogenic capacity of the used strain (3), evidenced by low agglutinating antibodies titers (25). Perhaps increasing the antigenic mass of strain Hardjoprajitno in vaccine may improve its immunogenicity (3).

The neutralizing antibodies response revealed the existence of cross neutralizing antibodies of serovars wolffi and guaricura against hardjo, wolffi and guaricura. Costa et al. (6) verified cross protection against challenge with serovar hardjo in hamsters vaccinated with hardjo and wolffi bacterins.

\section{REFERENCES}

1. Abuchaim, D.M.; Dutra, N.L.F. Prevalência da leptospirose em bovinos da bacia leiteira de Porto Alegre, RS. Arq. Fac. Vet. UFRGS, 13: 55-60, 1985.

2. Alves, C.J. Influência de fatores ambientais sobre a proporção de caprinos soro-reatores para a leptospirose em cinco centros de criação do Estado da Paraíba, Brasil. São Paulo, 1995, 102p. (Ph.D. Thesis. Faculdade de Medicina Veterinária e Zootecnia. USP).

3. Bolin, C.A.; Cassells, J.A.; Zuerner, R.L.; Trueba, G. Effect of vaccination with a monovalent Leptospira interrogans serovar hardjo type hardjo-bovis vaccine on type hardjo-bovis infection of cattle. Am. J. Vet. Res., 52: 1639-1643, 1991.

4. Caldas, E.M.; Viegas, E.A.; Viegas, S.A.R.A.; Reis, R.S. Aglutininas anti-leptospira em hemosoro de animais domésticos no Estado da Bahia, 1994/96 - II. Arq. Esc. Med. Vet. UFBA, 18: 268-280, 1995/ 96.

5. Corrêa, M.O.A.; Hyakutake, S.; Natale, V.; Galvão, P.A.; Aguiar, H.A. Estudos sobre a Leptospira wolffii em São Paulo. Rev. Inst. Adolfo Lutz, 25/27: 11-25, 1965/67.

6. Costa, M.C.R.; Moreira, E.C.; Leite, R.C.; Martins, N.R.S. Avaliação da imunidade cruzada entre Leptospira hardjo e L. wolffi. Arq. Bras. Med. Vet. Zootec., 50: 11-17, 1998.

7. Favero, A.C.M.; Mangerona, A.C.S.; Alessi, L.J.; Morais, Z.M.; Pinheiro, S.R.; Ferreira Neto, J.S.; Vasconcellos, S.A. Aglutininas pós-vacinais em bovinos imunizados com bacterina tetravalente contra a leptospirose. Influências de reações pré-vacinais, homólogas e heterólogas. Arq. Inst. Biol. São Paulo, 64: 45-55, 1997.

8. Favero, A.C.M. Estudo retrospectivo dos exames sorológicos de leptospirose realizados pelo Laboratório de Zoonoses Bacterianas da Faculdade de Medicina Veterinária e Zootecnia da Universidade 
de São Paulo, no período de 1984 a 1997. São Paulo, 2000, 115p. (Master Thesis. Faculdade de Medicina Veterinária e Zootecnia. USP).

9. Freudenstein, H.; Hein, B. Potency of leptospiral vaccines and protection against chronic infection in golden hamsters. Comp. Immun. Microbiol. Infect. Dis., 14: 229-234, 1991.

10. Galton, M.M.; Sulzer, C.S.; Santa Rosa, C.A.; Fields, M.J. Application of a microtechnique to the agglutination test for leptospiral antibodies. Appl. Microbiol., 13: 81-85, 1965.

11. Giorgi, W.; Genovez, M.E.; Teruya, J.M.; Silva, A.S. Leptospira interrogans, sorotipo wolffi, isolada de camundongo capturado no Porto de Santos, SP. Biológico, 50: 295-297, 1984.

12. Girio, R.J.S.; Herreira, R.C.P.; Pereira, F.J.G.; Mathias, L.A. Pesquisa de infecção por Leptospira interrogans em animais da região de Nhecolândia, no Pantanal do Mato Grosso do Sul. Arq. Inst. Biol. S. Paulo, 65: 87, 1998. (Suplemento).

13. Hanson, L.E. Immunology of bacterial diseases, with special reference to leptospirosis. J. Am. Vet. Med. Assoc., 170: 991-994, 1977.

14. Langoni, H. Leptospirose: aspectos de saúde animal e saúde pública. Rev. Educ. Cont. CRMV-SP, 2: 52-58, 1999.

15. Lilenbaum, W.; Santos, M.R.C.; Barbosa, A.V. Leptospirose em reprodução animal: II. Bovinos do Estado do Rio de Janeiro, Brasil. Rev. Bras. Cienc. Vet., 2: 1-6, 1995.

16. Mancuso, P.C. Titulagens: Kärber ou Reed_Muench? Bol. Inst. Pesq. Vet. Desid. Finamor, 2: 59-71, 1974.

17. Moreira, E.C.; Silva, J.S.; Viana, F.C.; Santos, W.L.M.; Anselmo, F.P.; Leite, R.C. Leptospirose bovina I. Aglutininas anti-leptospiras em soros sangüíneos de bovinos de Minas Gerais. Arq. Esc. Vet. UFMG, 31: 375-388, 1979.

18. Moreira, E.C. Avaliação de métodos para erradicação de leptospiroses em bovinos leiteiros. Minas Gerais, 1994, 94p. (Ph.D. Thesis. Escola de Veterinária. UFMG).

19. Myers, D.M. Manual de métodos, para el diagnostico de laboratorio de la leptospirosis. OPAS, Martinez, 1985. (Nota técnica n.30).

20. Pizzi, M. Sampling variation of the fifty per cent end-point, determined by the Reed-Muench (Behrens) method. Hum. Biol., 22: 151-190, 1950.

21. Ribeiro, S.C.A.; Silva, P.C.; Barbosa, F.C.; Gouveia, M.A.V.; Oliveira, P.R.; Mamede, D.O. Levantamento sorológico em dois surtos de leptospirose bovina, em Uberlândia, Triângulo Mineiro. Arq. Bras. Med. Vet. Zootec., 40: 415-423, 1988.

22. Samina, I.; Brenner, J.; Moalem, U.; Berenstein, M.; Cohen, A.; Peleb, B.A. Enhanced antibody response in cattle against Leptospira hardjo by intradermal vaccination. Vaccine, 15: 1434-1436, 1997.

23. Santa Rosa, C.A.; Pestana de Castro, A.F.; Silva, A.S.; Teruya, J.M. Nove anos de leptospirose no Instituto Biológico de São Paulo. Rev. Inst. Adolfo Lutz, 29/30: 19-27, 1969/70.

24. Santa Rosa, C.A.; Sulzer, C.R.; Pestana de Castro, A.F.; Yanaguita, R.M.; Giorgi, W. Two new leptospiral serovars in the Hebdomadis groups isolated from cattle in Brazil. Int. J. Zoon., 7: 158-163, 1980.

25. Siddique, I.H.; Shah, S.M. Evaluation of polyvalent leptospiral vaccine in hamsters. Ind. Vet. J., 67: 1006-1010, 1990.

26. Tripathy, D.N.; Hanson, L.E.; Mansfield, M.E. Growth inhibition test for measurement of immune response of animals vaccinated with leptospiral bacterins. $77^{\text {th }}$ Annual Meeting of the United States Animal Health Association, St. Louis, 1973, p.113-118.

27. United States of America. Supplemental assay method for potency assay of Leptospira interrogans serotype pomona bacterins. Ames, USDA Veterinary Services, 1977, 11p. (SAM608 - 9CFR 113.86).

28. Vasconcellos, S.A.; Barbarini Junior, O.; Umehara, O.; Morais, Z.M.; Cortez, A.; Pinheiro, S.R.; Ferreira, F.; Favero, A.C.M.; Ferreira Neto, J.S. Leptospirose bovina. Níveis de ocorrência e sorotipos predominantes em rebanhos dos Estados de Minas Gerais, São Paulo, Rio de Janeiro, Paraná, Rio Grande do Sul e Mato Grosso do Sul. Período de janeiro a abril de 1996. Arq. Inst. Biol. S. Paulo, 64: 7$15,1997$.

29. Vasconcellos, S.A.; Oliveira, J.C.F.; Morais, Z.M.; Baruselli, P.S.; Amaral, R.; Pinheiro, S.R.; Ferreira, F.; Ferreira Neto, J.S.; Schönberg, A.; Hartskeerl, R. Isolation of Leptospira santarosai, serovar guaricura from buffaloes (Bubalus bubalis) in Vale do Ribeira, São Paulo, Brazil. Braz. J. Microbiol., 32: 298-300, 2001.

30. Yanaguita, R.M. Contribuição ao estudo da leptospirose bovina, isolamento de dois novos sorotipos no sorogrupo Hebdomadis: sorotipos guaicurus $e$ goiano. São Paulo, 1972, 71p. (Ph.D. Thesis. Instituto de Ciências Biomédicas. USP).

31. Zemjanis, R. Vaccination for reproductive efficiency in cattle. $J$. Am. Vet. Med. Assoc., 165: 689-692, 1974. 